\title{
Maternal low-protein diet programmes offspring growth in association with alterations in yolk leptin deposition and gene expression in yolk-sac membrane, hypothalamus and muscle of developing Langshan chicken embryos
}

\author{
Kaiqing $\operatorname{Rao}^{1,2} \dagger$, Jingjing Xie ${ }^{1} \dagger$, Xiaojing Yang ${ }^{1} \dagger$, Lei Chen ${ }^{1}$, Roland Grossmann ${ }^{3}$ and Ruqian Zhao ${ }^{1 *}$ \\ ${ }^{1}$ Key Laboratory of Animal Physiology and Biochemistry, Nanjing Agricultural University, Nanjing 210095, People's Republic of \\ China \\ ${ }^{2}$ College of Life Science and Technology, Southwest University for Nationalities, Chengdu 610041, People's Republic of China \\ ${ }^{3}$ Department of Functional Genomics and Bioregulation, Institute of Farm Animal Genetics, Mariensee, 31535 Neustadt a Rbg, \\ Germany
}

(Received 17 September 2008 - Revised 12 December 2008 - Accepted 30 January 2009 - First published online 9 March 2009)

\begin{abstract}
The present study was aimed to investigate the mechanism underlying the influence of maternal low-protein (LP) diet on offspring growth in the chicken. One hundred and twenty Chinese inbred Langshan breeder hens were allocated randomly into two groups fed diets containing low (10\%, LP) or normal (15\%) crude protein levels. Low dietary protein did not affect the body weight of hens, but significantly decreased the laying rate and egg weight. The yolk leptin content was significantly lower in eggs laid by LP hens, while no differences were detected for yolk contents of corticosterone, tri-iodothyronine $\left(\mathrm{T}_{3}\right)$ or thyroxine. Despite significantly lower hatch weight, the LP offspring demonstrated obviously higher serum $\mathrm{T}_{3}$ concentration, which is in accordance with the faster post-hatch growth rate achieving significantly heavier body weight and pectoralis major muscle weight 4 weeks post-hatching. Expression of 20-hydroxysteroid dehydrogenase (20-HSD) mRNA in the yolk-sac membrane was significantly down-regulated at embryonic day 14, whereas that of transthyretin and leptin receptor (LepR) was not altered. Moreover, hypothalamic expression of 20-HSD, glucocorticoid receptors, thyrotropin-releasing hormone and LepR mRNA was significantly up-regulated in the LP group compared with their control counterparts. In the pectoralis major muscle, significantly higher expression of insulin-like growth factor (IGF)-I and IGF-I receptor mRNA was observed in LP embryos. The present study provides evidence that maternal LP diet programmes post-hatch growth of the offspring. The associated alterations in yolk leptin deposition as well as in yolk-sac membrane, fetal hypothalamus and muscle gene expression may be involved in mediating such programming effect in the chicken.
\end{abstract}

Maternal low-protein diet: Eggs: Yolk-sac membrane: Hypothalamus: Muscle: Corticosterone: Leptin: Thyroid hormone: Gene expression: Chickens

Maternal malnutrition during pregnancy and/or lactation exerts long-term effects on fetal development and postnatal growth, and may predispose offspring to metabolic diseases later in life ${ }^{(1)}$. Maternal low-protein (LP) diet or dietary protein restriction has been widely adopted as a model to reveal the possible mechanisms. The majority of the studies were carried out in mammals, and there are evidences that maternal LP diet alters endocrine status of the mother and placenta serves as a gateway to selectively relay the signals from mother to developing embryos ${ }^{(2)}$. As a result, expression profiles for specific genes or gene networks in specific tissues of developing fetus are modified ${ }^{(3)}$, which, consequently, induces phenotypic changes later in life.
In mammals, glucocorticoid ${ }^{(4)}$, thyroid hormones ${ }^{(5)}$ and leptin $^{(5,6)}$ are the major hormones mediating the programming effect of maternal nutrition on offspring performances. Although, potentially, all the tissues are affected by maternal malnutrition, placenta and fetal brain are the most intensively studied and are believed to be highly susceptible to prenatal environment. In the placenta, three representative genes are reported to participate in the endocrine mediation of maternal influences on fetal development, namely $11 \beta$-hydroxysteroid dehydrogenase 2 , which inactivates cortisol to cortisone to protect the fetus from overexposure to glucocorticoid ${ }^{(7)}$, leptin receptor (LepR), which mediates the action of leptin ${ }^{(8)}$, and transthyretin (TTR), a thyroxine $\left(\mathrm{T}_{4}\right)$-binding protein to

\footnotetext{
Abbreviations: Con, control; CRH, corticotropin-releasing hormone; E14, embryonic day 14; GR, glucocorticoid receptor; HPA, hypothalamic-pituitary-adrenal; 20-HSD, 20-hydroxysteroid dehydrogenase; IGF, insulin-like growth factor; IGF-IR, IGF-I receptor; LepR, leptin receptor; LP, low protein; $\mathrm{T}_{3}$, tri-iodothyronine; $\mathrm{T}_{4}$, thyroxine; TRH, thyrotropin-releasing hormone; TTR, transthyretin.

* Corresponding author: Dr Ruqian Zhao, fax + 86 2584398669, email zhao.ruqian@gmail.com

$\dagger$ These authors contributed equally to the work.
} 
transport thyroid hormones into the embryo ${ }^{(9)}$. In the brain, corticotropin-releasing hormone $(\mathrm{CRH})$ and thyrotropinreleasing hormone (TRH) are hypothalamic-releasing factors of the hypothalamic-pituitary-adrenal (HPA) and hypothalamic-pituitary-thyroid axes, respectively, which determines the 'set point' for growth and metabolism, as well as energy homeostasis. Corticosterone metabolic enzymes, glucocorticoid receptor (GR) and LepR expressed in the hypothalamus have been shown to fine-tune the HPA and hypothalamicpituitary-thyroid functions ${ }^{(10-12)}$. It has been suggested that maternal nutritional or endocrine intervention may modify the pattern of gene expression in the fetal hypothalamus and thus cause a shift of the metabolic set point in mammals ${ }^{(13)}$.

Birds offer some advantages over mammals in investigating the maternal influence or developmental programming because all the signals to be passed from mother to offspring are deposited in the egg. The hormone-mediated maternal effects have been investigated both descriptively and experimentally in birds, focusing on the effects of yolk steroids, especially testosterone, on postnatal growth and behaviour ${ }^{(14)}$. By far, most of the work is related to behaviour ecology using wild birds as a model, and the maternal hormones in the egg yolk concern mainly sex steroids ${ }^{(15)}$, glucocorticoids ${ }^{(16)}$ or thyroid hormones ${ }^{(17)}$. Recently, we reported leptin deposition in the chicken egg and its correlations with maternal leptin concentrations in the plasma and liver, as well as embryonic and post-hatch growth of the offspring ${ }^{(18)}$, adding a new member to the list of yolk hormones in avian species.

Nevertheless, it remains largely unknown how maternal hormones deposited in the egg yolk exert their actions on the embryo. Two basic questions need to be answered. First, are genes encoding response components such as metabolic enzymes, transporters or receptors expressed on the yolk-sac membrane and responsive to maternal nutrition? Second, what tissues and genes in the developing embryo are affected and how such modifications are associated with phenotypic changes of the offspring?

It is well known that nutritional interventions, such as fasting and protein deficiency, induce significant alterations in the endocrine status of chickens ${ }^{(19)}$. However, there are scarcely any data linking maternal nutrition to yolk hormone deposition and progeny embryonic development in domestic fowls, and the pathways through which the maternal hormones in the yolk programme the progeny development and growth have not been examined.

Therefore, the present study was aimed to test the hypothesis that maternal LP diet may programme offspring growth by modifying maternal hormone deposition in the yolk and subsequently or simultaneously altering the pattern of gene expression in important tissues of developing chicken embryos. Metabolic hormones including corticosterone, thyroid hormone and leptin were measured. Yolk-sac membrane as a mother-offspring interface, fetal hypothalamus representing central regulatory system and pectoralis major muscle as an indication for fetal growth were sampled at embryonic day 14 (E14) to monitor the alterations in the pattern of gene expression. Genes presumably involved in mother-offspring signal transportation including 20-HSD, TTR and LepR in the yolk-sac membrane, genes participating in central metabolic regulation such as $20-\mathrm{HSD}, \mathrm{GR}, \mathrm{TRH}, \mathrm{CRH}$ and LepR in the hypothalamus, as well as genes regulating muscle growth such as insulin-like growth factors I and II (IGF-I and IGF-II) and IGF-I receptor (IGF-IR), were selected as targets of investigation.

\section{Materials and methods}

\section{Animals and experimental design}

A highly inbred Chinese indigenous broiler chicken strain, Langshan, was employed in the present study in order to ensure the homogeny of the genetic background, as most of the commercial broiler chicken lines are hybrids and may cause high individual variations. One hundred and twenty 44-week-old Langshan breeder hens were selected from the parent stock kept in the Institute of Poultry Science, Chinese Academy of Agricultural Sciences (Yangzhou, China) and randomly allocated to the control (Con) and LP diet groups. The Con group was fed a standard diet containing $15 \%$ crude protein according to the nutritional standard established for the breed, while the LP group was fed diets with $10 \%$ crude protein. Lysine and methionine contents were adjusted accordingly, while energy, vitamins and trace element contents were kept the same in the two groups. The diet composition is shown in Table 1. Hens were artificially inseminated. Eggs were collected in the 4th week after the initiation of the dietary treatment. The experiment lasted for a month. Body weight of hens was recorded at the beginning and the end of the experiment.

Eggs of similar size (ten for each group) were used to determine the yolk content of tri-iodothyronine $\left(\mathrm{T}_{3}\right), \mathrm{T}_{4}$ and leptin using RIA, and corticosterone using enzyme immunoassay.

Table 1. Composition of the basal diet used in the present experiment

\begin{tabular}{lccc}
\hline & \multicolumn{2}{c}{ Breeder hens } & \\
\cline { 2 - 3 } & Control & Low-protein & $\begin{array}{c}\text { Broilers } \\
\text { Starter }\end{array}$ \\
\hline Ingredients (\%) & & & \\
Maize & 67.46 & 76.99 & 66.58 \\
Soyabean meal & 20.22 & 7.11 & 27.26 \\
Limestone & 7.98 & 8.05 & 1.59 \\
NaCl & 0.30 & 0.30 & 0.30 \\
Vitamin premix & 0.25 & 0.25 & 0.50 \\
Mineral premix & 0.25 & 0.25 & 0.50 \\
Vegetable oil & - & - & 2.0 \\
Attapulgite & 1.81 & 5.28 & - \\
Dicalcium phosphate & 1.42 & 1.49 & 0.72 \\
D,L-Met & 0.12 & 0.06 & 0.20 \\
L-Lys & 0.13 & 0.20 & 0.18 \\
Cystine & 0.06 & 0.02 & 0.17 \\
Calculated composition (\%) & & & \\
Metabolisable energy (MJ/kg) & 11.08 & 11.08 & 12.13 \\
Crude protein & 15.0 & 10.0 & 17.0 \\
Lys & 0.80 & 0.54 & 1.00 \\
Met & 0.36 & 0.24 & 0.45 \\
Met + cystine & 0.62 & 0.43 & 0.92 \\
Ca & 3.20 & 3.20 & 1.00 \\
P & 0.54 & 0.54 & 0.50 \\
\hline
\end{tabular}

*Vitamin premix provided (per kg of diet): vitamin A, $84000 \mathrm{IU}$; vitamin $\mathrm{D}_{3}, 1500 \mathrm{IU}$; vitamin $\mathrm{E}, 11 \mathrm{mg}$; vitamin $\mathrm{K}_{3}, 1.5 \mathrm{mg}$; thiamine, $1.1 \mathrm{mg}$; riboflavin, $6.6 \mathrm{mg}$; niacin $66 \mathrm{mg}$; pantothenic acid, $16.5 \mathrm{mg}$; biotin, $0.11 \mathrm{mg}$; folic acid, $1.1 \mathrm{mg}$; vitamin $B_{12}$, $13.2 \mathrm{~g}$; ethoxyquin, $125 \mathrm{mg}$.

† Mineral premix provided (per kg of diet): manganese sulphate, $68 \mathrm{mg}$; zinc oxide, $55 \mathrm{mg}$; iron sulphate, $26 \mathrm{mg}$; copper sulphate, $4.4 \mathrm{mg}$; iodine, $1.0 \mathrm{mg}$; selenuim, $0.1 \mathrm{mg}$. 
The yolk was separated from the albumen, homogenised and stored at $-20^{\circ} \mathrm{C}$ before the analysis.

One hundred and forty eggs from each group were incubated at $37.8^{\circ} \mathrm{C}$ with $60-70 \%$ relative humidity following standard settings for automatic turning and ventilation. The eggs in Con and experiment groups were placed side by side and distributed equally on different shelves in the incubator to minimise the possible variations in the incubation condition. On E14, ten eggs from each group were taken from matched location for tissue sampling. The egg weight and embryo weight were recorded and the yolk sac was immediately removed and washed twice in saline. The pectoralis major muscle and the hypothalamus were dissected. All the tissue samples were snap-frozen in liquid $\mathrm{N}_{2}$ and then transferred to $-80^{\circ} \mathrm{C}$ until RNA extraction. The remaining eggs were incubated until hatch. At hatching, ten chicks from each group were killed for plasma and tissue sampling. The remaining chicks were reared under the same diet (Table 1) until 4 weeks of age. The body weight was recorded every week and the pectoralis major muscle was dissected and weighed at 1 and $28 \mathrm{~d}$ of age.

The experiment was undertaken following the guidelines of the Animal Ethics Committee in Nanjing Agricultural University.

\section{Hormone assays}

RIA. All hormones except corticosterone were measured using commercial RIA kits. Multi-species leptin RIA kit was purchased from Beijing North Institute of Biotechnology (Beijing, China) with an intra-assay $\mathrm{CV}$ of $5 \%$. Total $\mathrm{T}_{3}$ and $\mathrm{T}_{4}$ RIA kits were purchased from Shanghai Institute of Biological Products (Shanghai, China) with an intra-assay $\mathrm{CV}$ of $5 \%$ for both kits. Egg yolk samples were extracted, as previously described ${ }^{(17)}$, for thyroid hormone analysis. Yolk leptin was extracted according to De Pablo et al. ${ }^{(20)}$. All samples were analysed in duplicate within one assay to avoid inter-assay variations. The commercial RIA kits were validated for measuring chicken samples ${ }^{(18,21)}$.

Enzyme immunoassay. Yolk corticosterone was extracted before assay according to Williams et al. ${ }^{(22)}$ and was determined with a commercial enzyme immunoassay kit (Cayman Chemical Company, Ann Arbor, MI, USA; catalogue number: 500651-96). The detection range of the kit was $24-10000 \mathrm{pg} / \mathrm{well}$, and all determinations fell within this range. The inter- and intra-assay $\mathrm{CV}$ were 3.5 and $8.4 \%$, respectively. The cross-reactivity of the antibody with other steroids was $<0.5 \%$.

\section{Total RNA extraction}

A portion (about $30 \mathrm{mg}$ ) of the yolk-sac membrane and pectoralis major muscle were used to extract total RNA using TRIzol total RNA kit (Tiangen Biotech Co., Ltd, Beijing, China). The whole hypothalamus was ground in liquid $\mathrm{N}_{2}$ and a portion of about $50 \mathrm{mg}$ was used for RNA extraction. The total RNA concentration was quantified by measuring the absorbance at $260 \mathrm{~nm}$ in a photometer (Eppendorf Biophotometer, Hamburg, Germany). The 260:280 ratios of all preparations were between $1 \cdot 8$ and $2 \cdot 0$. Aliquots of RNA samples were subjected to electrophoresis through a $1.4 \%$ agarose-formaldehyde gel to verify their integrity.

\section{Reverse transcription}

Two micrograms of total RNA were reverse transcribed by incubation at $37^{\circ} \mathrm{C}$ for $1 \mathrm{~h}$ for the first-strand cDNA synthesis in a $25 \mu \mathrm{l}$ mixture consisting of $1 \times$ reverse transcription buffer, $10 \mathrm{~mm}$-deoxynucleotide triphosphates, $10 \mathrm{U}$ RNase inhibitor, $100 \mathrm{U}$ moloney murine leukaemia virus reverse transcription and $2.5 \mu \mathrm{M}$ random hexamer primers. The reaction was terminated by heating at $95^{\circ} \mathrm{C}$ for $5 \mathrm{~min}$ and quickly cooling on ice.

\section{Real-time PCR}

Real-time PCR were performed in Mx3000P (Stratagene, La Jolla, CA, USA). Different controls were set to monitor the possible contamination of genomic and environmental DNA both at the stage of reverse transcription and polymerase chain reaction. The pooled sample made by mixing equal quantity of total RNA from all samples was used for optimising the PCR condition and tailoring the standard curve. Melting curves were performed to confirm specific amplification for each gene. Two microlitres of the reverse transcription product, diluted 8- to 16-fold, were used in a final volume of $25 \mu \mathrm{l}$ containing $12.5 \mu \mathrm{l}$ synergy brands green real-time PCR master mix (code number: QPK-201; Toyobo, Japan) and $0.2-0.8 \mu \mathrm{mol} / \mathrm{l}$ primer pairs for IGF-I, IGF-II, IGF-IR, 20-HSD, TTR, GR, CRH, TRH and LepR, and chicken $\beta$-actin was used as a reference gene for normalisation purposes. The PCR products were sequenced for verifying specificities. The primer sequences and PCR conditions for each gene are shown in Table 2.

\section{Statistical analysis}

The method of $2^{-\Delta \Delta C T}$ was used to analyse the real-time PCR data expressed as the fold change relative to the Con group $^{(23)}$. All data were presented as mean values with their standard errors. Statistical analyses were carried out with SPSS 11.0 for Windows (SPSS Inc., Chicago, IL, USA). The differences were tested with ANOVA using $t$ test for independent samples. A $P$-value $<0.05$ was considered significant.

\section{Results}

Performance of hens and offspring

Low dietary protein level did not affect the body weight of hens, but significantly $(P<0 \cdot 05)$ decreased egg weight and the laying rate (Table 3 ). LP diet did not affect the fertility rate (LP $97.4 \% \quad v$. Con $97.7 \%$ ), but decreased hatchability of fertile eggs from 82.9 to $74.5 \%$. Since no replicates were set up for each group during incubation, statistical analysis was not possible for fertility or hatchability. Embryo weight at E14 did not show difference between the two groups, but both body weight and pectoralis major muscle weight at hatching were significantly decreased in the LP group compared with the Con $(P<0.001$ and $P=0.024$, respectively). The LP 
Table 3. Effect of low-protein (LP) diet on breeder body weight ( $n$ 15), egg weight $(n 120)$ and egg-laying rate $(n 30)$

(Mean values with their standard errors)

\begin{tabular}{|c|c|c|c|c|c|c|c|c|}
\hline \multirow[b]{2}{*}{ Groups } & \multicolumn{2}{|c|}{$\begin{array}{l}\text { Initial body } \\
\text { weight }(\mathrm{g})\end{array}$} & \multicolumn{2}{|c|}{$\begin{array}{l}\text { Final body } \\
\text { weight }(\mathrm{g})\end{array}$} & \multicolumn{2}{|c|}{$\begin{array}{l}\text { Egg weight } \\
\text { (g) }\end{array}$} & \multicolumn{2}{|c|}{$\begin{array}{c}\text { Egg-laying } \\
\text { rate }(\%)\end{array}$} \\
\hline & Mean & $\overline{\text { SEM }}$ & Mean & $\overline{\mathrm{SEM}}$ & Mean & $\overline{\text { SEM }}$ & Mean & SEN \\
\hline & & 61 & & 63 & & & & $2 \cdot \xi$ \\
\hline$P$ & 1921 & 30 & 1862 & 32 & $48.91^{*}$ & 0.27 & $59 \cdot 0^{\star *}$ & $2 \cdot 8$ \\
\hline
\end{tabular}

Mean values were significantly different from that of the control group: ${ }^{\star} P<0.05$, ${ }^{\star *} P<0.01$.

offspring demonstrated significantly higher post-hatch growth rate, which resulted in significantly heavier body weight and pectoralis major muscle weight $(P=0.047$ and $0 \cdot 001$, respectively) at 4 weeks post-hatching (Table 4$)$.

\section{Plasma and yolk hormone concentration}

The yolk leptin content was significantly lower in eggs laid by LP hens $(P=0 \cdot 026)$, while no differences were detected for yolk contents of corticosterone, $\mathrm{T}_{3}$ or $\mathrm{T}_{4}(P=0.314,0.72$ and 0.066 , respectively). The LP offspring had significantly higher serum $\mathrm{T}_{3}$ concentration at hatching $(P=0 \cdot 006)$, yet no difference was found in plasma $\mathrm{T}_{4}(P=0 \cdot 228$; Table 5).

\section{Gene expression in yolk-sac membrane, hypothalamus and} pectoralis major muscle

As shown in Fig. 1, 20-HSD mRNA expression was significantly down-regulated in the yolk-sac membrane of the LP embryo at E14 $(P=0.043)$, whereas no significant alterations were observed for the TTR and LepR mRNA expression $(P=0.943$ and 0.376 , respectively).

Hypothalamic expression of 20-HSD, GR, TRH and LepR increased significantly in LP embryos compared with their control counterparts $(P=0 \cdot 04,0 \cdot 016,0.024$ and 0.024 , respectively), while no difference was observed for the CRH mRNA expression ( $P=0.737$; Fig. 2 ).

In the pectoralis major muscle, expression of IGF-I and IGF-IR mRNA was significantly increased $(P=0.011$ and $0 \cdot 019$, respectively) in LP embryos, while that of IGF-II mRNA was not affected by maternal dietary protein restriction $(P=0 \cdot 069$; Fig. 3).

\section{Discussion}

Stringent feed restriction has been a routine practice in the broiler breeder management to reduce body size in order to improve egg production. Earlier studies demonstrated that reducing crude protein intake of broiler breeders from 16 to $10 \%$, while maintaining intake of critical amino acids, reduced egg weight and hatch weight, but no lasting effect was observed on offspring weight at $48 \mathrm{~d}$, suggesting a catchup growth after hatching ${ }^{(24)}$. Unfortunately, this phenomenon did not attract enough attention beyond its economic significance at the time and the underlying mechanism was not explored. The catch-up growth or compensatory growth in the progeny of hens fed LP diet was also observed in the 
Table 4. Effect of maternal low-protein (LP) diet on body weight and pectoralis muscle weight (Mean values with their standard errors)

\begin{tabular}{|c|c|c|c|c|c|c|c|c|c|c|}
\hline \multirow[b]{3}{*}{ Groups } & \multicolumn{6}{|c|}{ Body weight (g) } & \multicolumn{4}{|c|}{ Pectoralis muscle weight (g) } \\
\hline & \multicolumn{2}{|c|}{$\mathrm{E} 14(n 10)$} & \multicolumn{2}{|c|}{$\mathrm{D} 1(n 99)$} & \multicolumn{2}{|c|}{$\mathrm{D} 28(n 10)$} & \multicolumn{2}{|c|}{$\mathrm{D} 1(n 10)$} & \multicolumn{2}{|c|}{$\mathrm{D} 28(n 10)$} \\
\hline & Mean & SEM & Mean & SEM & Mean & SEM & Mean & SEM & Mean & SEM \\
\hline Control & $10 \cdot 31$ & 0.57 & 34.93 & 0.27 & 174.68 & 4.46 & 0.18 & 0.01 & $2 \cdot 52$ & 0.24 \\
\hline LP & 8.84 & 0.91 & $33.42^{\star \star \star}$ & 0.30 & $185 \cdot 96^{*}$ & 3.33 & $0.15^{\star}$ & 0.01 & $3.82^{\star *}$ & 0.23 \\
\hline
\end{tabular}

E14, embryonic day 14; D1, day 1; D28, day 28.

Mean values were significantly different from that of the control group: ${ }^{\star} P<0.05,{ }^{\star \star} P<0.01,{ }^{\star \star \star} P<0.001$.

present study, although the contents of limiting amino acids were adjusted according to the crude protein values. However, the deficiencies of limiting amino acids, especially methionine and lysine, may be responsible for the decreased laying rate observed in the present study in LP hens, which is in accordance with the early finding ${ }^{(25)}$.

Maternal nutrition may programme placental function, offspring embryogenesis and postnatal growth in mammals ${ }^{(1)}$. In birds, sex steroid hormones ${ }^{(14,15)}$, corticosterone ${ }^{(16)}$, thyroid hormones $^{(17)}$ and, recently, leptin ${ }^{(18)}$ have been reported to be present in egg yolk and presumably involved in mediating the maternal effect. While most of the experiments applied hormone supplementation to achieve alterations in maternal endocrine status and thus yolk hormone contents, few studies focused on alterations of hormone content in egg yolk induced by maternal nutrition. We determined the yolk content of corticosterone, $T_{3}$ and $T_{4}$, as well as leptin in the present study and all the values were similar to what was previously reported $^{(16,18,26)}$. No differences were detected for yolk corticosterone, $\mathrm{T}_{3}$ or $\mathrm{T}_{4}$, but leptin content was found to be significantly reduced in the yolk of eggs laid by hens fed LP diet. Since no significant alterations were found in egg composition and egg quality traits (data not shown), and eggs of similar size were used for measuring yolk hormones, it is unlikely that the reduced yolk leptin content in LP eggs was a consequence of altered egg characteristics.

Chicken leptin has been a sensitive and widely disputed issue $^{(27)}$. Discrepancies in detecting leptin gene expression in chicken and failure to map the published chicken leptin sequence to chicken genome led to a conclusion that the existence of chicken leptin gene and its encoded protein has not been clarified. However, leptin or leptin-like immunoreactivity has been detected in chicken plasma ${ }^{(28)}$, gastroenteric tract $^{(29)}$, as well as liver and egg $^{(18)}$ by using RIA, immunocytochemistry and/or Western blot analysis. Furthermore, the existence of a functional chicken $\operatorname{LepR}^{(30)}$ and the biological responses of different systems in the chicken to exogenous recombinant leptin ${ }^{(31-34)}$ strongly suggest the presence of a leptin-like signalling system in the chicken. The detected leptin-like immunoreactivity in the present and other studies may represent the endogenous ligand for LepR, which is yet to be identified.

Maternal LP isoenergetic diet significantly decreased maternal plasma leptin levels in rats ${ }^{(35)}$, yet no data are available describing the effect of protein restriction on leptin concentration in the chicken. Nevertheless, as in mammals, plasma leptin level in the chicken was also considered as an indicator for consistent food supply and more stable energy status ${ }^{(36)}$. Unfortunately, the plasma leptin concentration of hens was not measured in the present study, because any invasive procedure, other than modest dietary treatment, was not approved to apply to the highly protected parent stock of the pure-bred indigenous chicken. Therefore, the effect of LP diet on plasma leptin concentration in breeder hens and the correlation between leptin levels in plasma of hens and egg yolk are still to be determined.

Both maternal protein restriction ${ }^{(37,38)}$ and prenatal leptin exposure $^{(39)}$ have been shown to programme offspring performance in mammals. In the present study, the reduced yolk leptin content was found to be associated with faster post-hatch growth, which agrees with what we reported recently that higher yolk leptin content corresponded to attenuated post-hatch growth in offspring of dietary cysteaminetreated hens ${ }^{(18)}$. It is well known that chicken hatch weight is closely correlated with egg weight and, indeed, a strong positive correlation between egg weight and hatch weight

Table 5. Effect of maternal low-protein (LP) diet on yolk hormone contents and serum hormone concentrations in the progeny at hatching

(Mean values with their standard errors)

\begin{tabular}{|c|c|c|c|c|c|c|c|c|c|c|c|c|}
\hline \multirow[b]{3}{*}{ Groups } & \multicolumn{8}{|c|}{ Yolk (ng/g) } & \multicolumn{4}{|c|}{ Serum of $\mathrm{D} 1$ chicks $(\mathrm{ng} / \mathrm{ml})$} \\
\hline & \multicolumn{2}{|c|}{$\mathrm{T}_{3}$} & \multicolumn{2}{|c|}{$\mathrm{T}_{4}$} & \multicolumn{2}{|c|}{ Corticosterone } & \multicolumn{2}{|c|}{ Leptin } & \multicolumn{2}{|c|}{$\mathrm{T}_{3}$} & \multicolumn{2}{|c|}{$\mathrm{T}_{4}$} \\
\hline & Mean & SEM & Mean & SEM & Mean & SEM & Mean & SEM & Mean & SEM & Mean & SEM \\
\hline Control & 0.93 & 0.08 & $5 \cdot 28$ & 0.31 & $4 \cdot 70$ & 0.36 & 1.43 & 0.07 & 1.96 & 0.17 & $13 \cdot 12$ & 0.74 \\
\hline LP & 1.00 & 0.09 & $4 \cdot 61$ & 0.28 & $4 \cdot 13$ & 0.46 & $1.17^{\star}$ & 0.07 & $2 \cdot 71^{\star *}$ & 0.15 & $15 \cdot 32$ & 0.99 \\
\hline
\end{tabular}

D1, day $1 ; T_{3}$, tri-iodothyronine; $T_{4}$, thyroxine.

Mean values were significantly different from that of the control group $\left({ }^{\star} P<0.05,{ }^{\star \star} P<0.01, n 10\right)$. 

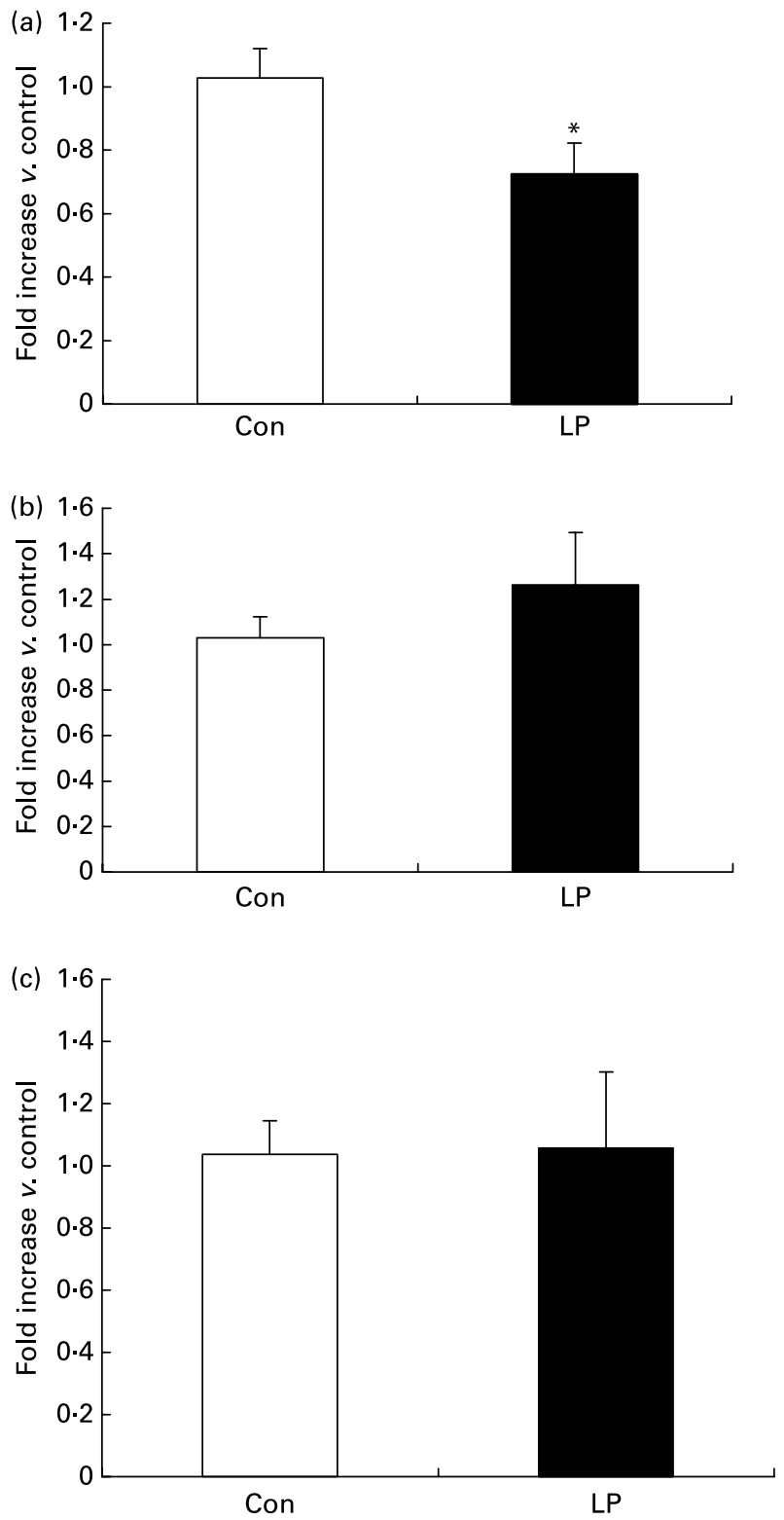

Fig. 1. Effect of maternal low-protein (LP) diet on mRNA expression of (a) 20-hydroxysteroid dehydrogenase, (b) leptin receptor and (c) transthyretin in the yolk-sac membrane of embryonic day 14 embryos. The difference between the two groups was significant $\left({ }^{\star} P<0 \cdot 05, n 10\right)$. Con, control.

$\left(R^{2} 0.9275, P<0 \cdot 01\right.$; data not shown) was observed in the present study. It is possible that the decreased hatch weight in the LP group resulted from the lower egg weight, but the significantly higher growth rate demonstrated in the LP offspring implicates a more complex mechanism.

Chicken embryo develops independent of the mother and all the nutritive substances and regulatory signals including hormones must be contained in the egg. The yolk sac envelops the yolk and produces enzymes and transporters that help to mobilise and transport the nutrients from the yolk to the developing embryo ${ }^{(40,41)}$. Similarly, for maternal hormones in the yolk to exert actions on the embryo, receptors, binding proteins or transporters for specific hormones must be present on the yolk-sac membrane. However, information is scarce regarding the expression and function of proteins responsible for maternal signal transportation or transduction in the yolk-sac membrane.

LepR mRNA was detected in the turkey yolk-sac membrane $^{(42)}$, but its function is largely unknown. Since leptin is found to exist in the chicken egg yolk, we assumed that yolk leptin may bind to its receptor on the yolk-sac membrane to achieve either its transfer across the membrane or its signal transduction to regulate the yolk-sac function per se. However, maternal LP diet did not affect the LepR mRNA expression in the chicken yolk-sac membrane, although the yolk leptin content was significantly reduced.

In mammals, maternal undernutrition and low birth weight was associated with the reduction of placental $11 \beta$-hydroxysteroid dehydrogenase 2 activity $^{(43)}$. In birds, 20-HSD is the most abundantly and more ubiquitously expressed enzyme, which transforms glucocorticoids to inactive 20-dihydrocorticosterone $^{(44)}$. We detected, for the first time, 20-HSD mRNA expression in the chicken yolk-sac membrane and a significantly decreased expression was shown in the LP group. It remains unknown how maternal protein restriction may affect the yolk-sac expression of 20-HSD. There is evidence indicating a role of leptin in regulating hepatic $11 \beta$-hydroxysteroid dehydrogenase 2 expression ${ }^{(45)}$. However, whether and how yolk leptin is involved in the regulation of yolk-sac 20-HSD mRNA expression is worthy of further investigation.

Serum $\mathrm{T}_{4}$-binding protein, TTR (formerly prealbumin), is made by hepatocytes and choroid plexus epithelium in adults and by yolk-sac cells in embryogenesis ${ }^{(46)}$. TTR is one of the important $\mathrm{T}_{4}$ transporters in birds and was suggested to transport thyroid hormones into the embryo ${ }^{(47)}$. However, neither yolk thyroid hormones nor TTR mRNA expression in the yolk sac were affected by maternal LP diet in the present study.

The hypothalamus is one of the most susceptible targets for fetal programming induced by maternal nutrition ${ }^{(1)}$ The chicken embryo is structurally complete by $\mathrm{E} 14^{(48)}$, and most of the neuroendocrine regulatory networks in the hypothalamus establish and start to function about this time $^{(49)}$. We speculated that the profiles of hypothalamic expression of genes involved in metabolic and energy homeostasis regulation may be modified by maternal protein restriction at this stage of chicken embryonic development. The HPA axis has been suggested to be one of the major targets for metabolic programming and is known to be involved not only in stress response, but also in energy homeostasis in mammals ${ }^{(50,51)}$. A short period $(48 \mathrm{~h})$ of maternal nutrient restriction inhibited $\mathrm{CRH}$ mRNA expression in the fetal hypothalamus of guinea pigs ${ }^{(52)}$, yet, in the present study, maternal LP diet did not affect hypothalamic CRH mRNA expression in E14 chicken embryos. A number of factors, including species, method of restriction, timing of sampling, etc., may contribute to such discrepancy.

It is known that peripheral corticosterone feeds back at the level of the hypothalamus to regulate $\mathrm{CRH}$ mRNA expression and thereby HPA function in the chicken ${ }^{(53)}$. Therefore, GR and corticosterone metabolic enzyme (20-HSD) in the hypothalamus may potentially be the targets for HPA programming. Indeed, mRNA expressions of GR and 20-HSD were both significantly up-regulated in the hypothalamus of 

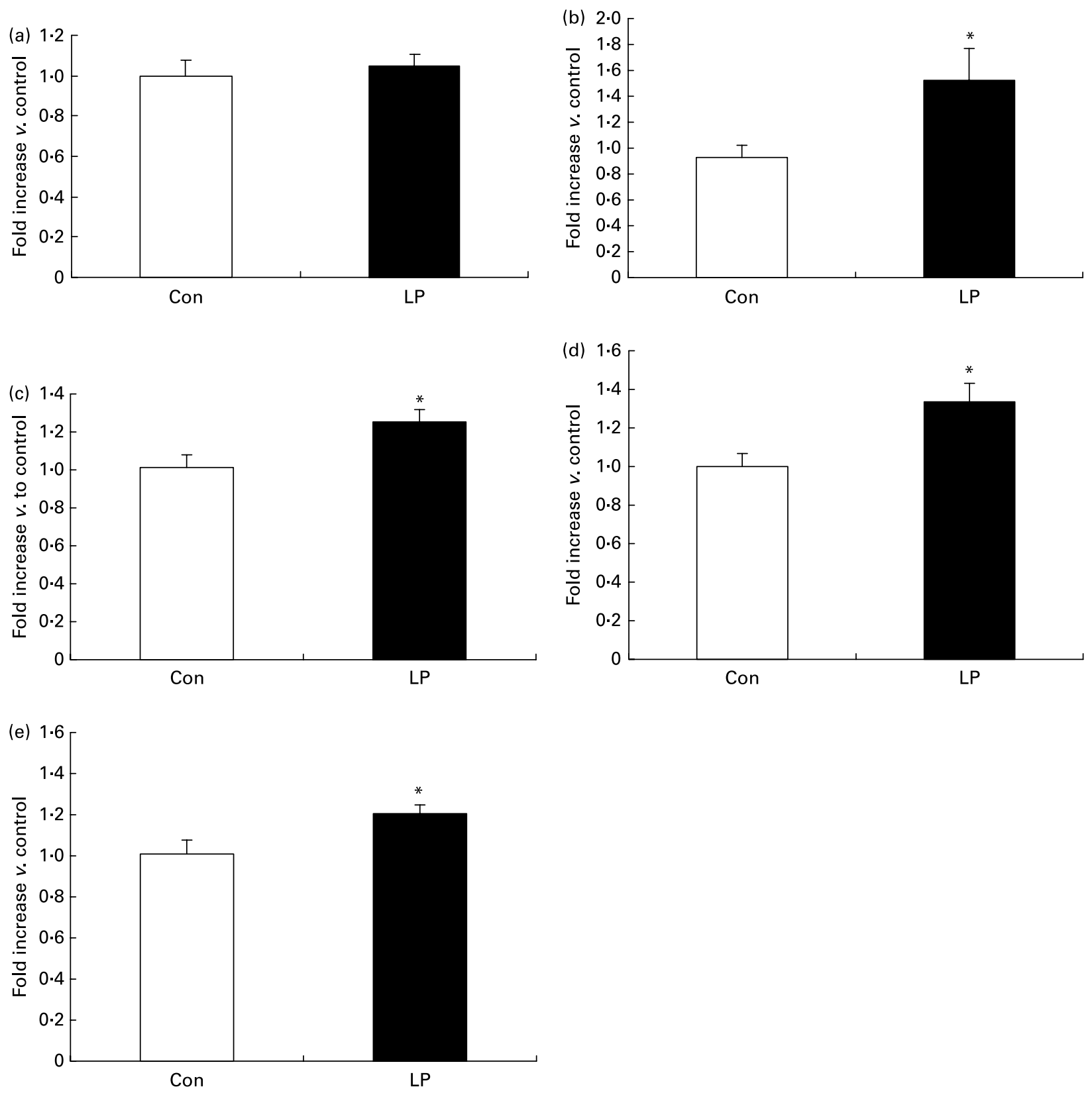

Fig. 2. Effect of maternal low-protein (LP) diet on mRNA expression of (a) corticotropin-releasing hormone, (b) thyrotropin-releasing hormone, (c) glucocorticoid receptor, (d) leptin receptor and (e) 20-hydroxysteroid dehydrogenase in the hypothalamus of embryonic day 14 embryos. The difference between the two groups was significant $\left({ }^{\star} P<0.05, n 10\right)$. Con, control.

E14 LP embryos, indicating a profound impact of maternal nutrition on the HPA axis in the chicken progeny.

TRH in the hypothalamus plays a major role in regulating the hypothalamic-pituitary-thyroid axis ${ }^{(54)}$, the most important neuroendocrine system in growth regulation in the chicken $^{(55)}$. We observed a significant up-regulation of TRH mRNA in the hypothalamus of the E14 embryo of the LP group, which may account, to some extent, for higher growth rate after hatching. However, it is unknown whether increased hypothalamic TRH mRNA expression at E14 is responsible for higher serum $\mathrm{T}_{3}$ at hatching, because no significant change was observed for serum $\mathrm{T}_{4}$ level. Other pathways, including the somatotropic axis, may be involved in the regulation of accelerated post-hatch growth in the LP progeny. The significant up-regulation of LepR mRNA expression in the hypothalamus may hint possible changes in the regulation of energy metabolism and homeostasis.

Skeletal muscle, especially breast muscle, is the major product in the broiler industry. In the present study, the LP offspring demonstrated significantly heavier body weight and pectoralis major muscle weight 4 weeks post-hatching. We hypothesised that maternal protein restriction may also programme myogenesis during chicken embryonic development. Among all the factors involved in regulating myogenesis, IGF-I and II are key regulators for vertebrate muscle development and growth through endocrine and/or paracrine/autocrine 

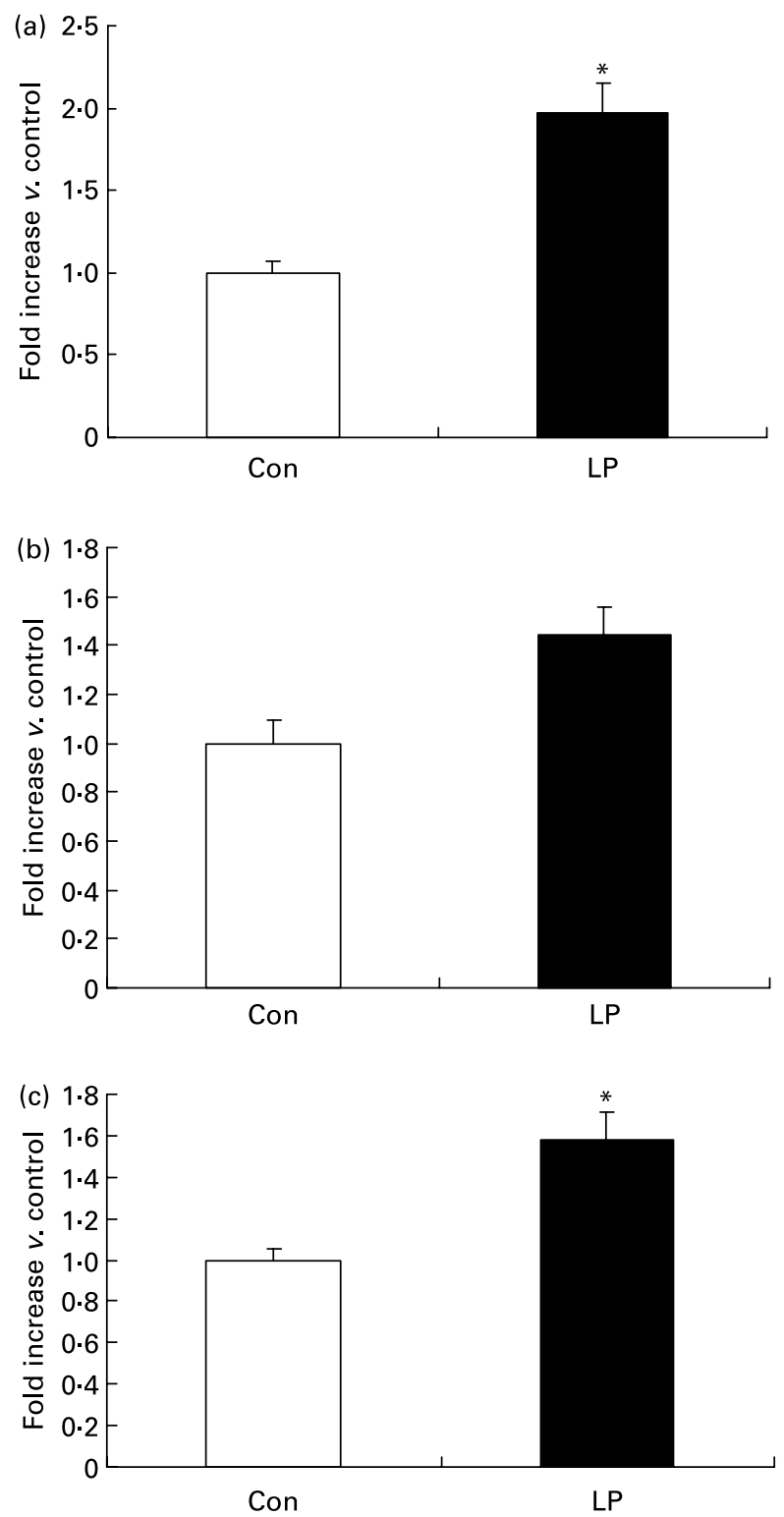

Fig. 3. Effect of maternal low-protein (LP) diet on mRNA expression of (a) insulin-like growth factor (IGF)-I, (b) IGF-II and (c) IGF-I receptor in the pectoralis muscle of embryonic day 14 embryos. The difference between the two groups was significant $\left({ }^{\star} P<0.05, n 10\right)$. Con, control.

pathways $^{(56)}$. In birds, locally produced IGF are more important for embryonic myogenesis since hepatic IGF-I mRNA expression and circulating IGF-I level were very low until the late stage of embryonic development ${ }^{(57)}$. Unlike mammalian species, both IGF-I and II seem to share a common receptor, IGF-IR, in birds ${ }^{(58)}$. Expression of IGF-I and IGF-IR mRNA was significantly up-regulated in the pectoralis major muscle of the LP offspring, while that of IGF-II showed a trend of increase, which may contribute, at least partly, to the accelerated muscle growth during early posthatch development.

Taken together, the present results demonstrated that maternal protein deficiency exerts a profound influence on embryonic development and post-hatch growth of the progeny, which is associated with modifications in leptin deposition in the yolk, as well as alterations in the pattern of gene expression in yolk-sac membrane, hypothalamus and muscle of developing chicken embryos. These results provide evidences for the fetal programming effect of maternal nutrition in the chicken, and offer hints for further investigations into the signal transmission pathways involved in mediating such effects.

\section{Acknowledgements}

The present work was supported by National Basic Research Program of China, 2004CB117505 (R. Z.) and Sino-German Bilateral Cooperation in Agriculture, No. 28 (R. Z. and R. G.). K. R., J. X. and X. Y. were responsible for the quantification of gene expression and contributed to the drafting of the manuscript; L. C. carried out the animal study, took samples and measured hormone levels; R. G. and R. Z. designed the experiment, supervised the whole process and finalised the manuscript. The authors have no conflicts of interest.

\section{References}

1. Symonds ME, Stephenson T, Gardner DS, et al. (2007) Longterm effects of nutritional programming of the embryo and fetus: mechanisms and critical windows. Reprod Fertil 19, $53-63$.

2. Myatt L (2006) Placental adaptive responses and fetal programming. J Physiol 572, 25-30.

3. Hanson MA \& Gluckman PD (2008) Developmental origins of health and disease: new insights. Basic Clin Pharmacol Toxicol 102, 90-93.

4. Drake AJ, Walker BR \& Seckl JR (2005) Intergenerational consequences of fetal programming by in utero exposure to glucocorticoids in rats. Am J Physiol Regul Integr Comp Physiol 288, R34-R38.

5. Mostyn A, Sebert S, Litten JC, et al. (2006) Influence of porcine genotype on the abundance of thyroid hormones and leptin in sow milk and its impact on growth, metabolism and expression of key adipose tissue genes in offspring. $J$ Endocrinol 190, 631-639.

6. Miralles O, Sánchez J, Palou A, et al. (2006) A physiological role of breast milk leptin in body weight control in developing infants. Obesity (Silver Spring) 14, 1371-1377.

7. Stewart PM \& Krozowski ZS (1999) 11 beta-Hydroxysteroid dehydrogenase. Vitam Horm 57, 249-324.

8. Baratta M (2002) Leptin - from a signal of adiposity to a hormonal mediator in peripheral tissues. Med Sci Monit 8, 282-292.

9. McKinnon B, Li H, Richard K, et al. (2005) Synthesis of thyroid hormone binding proteins transthyretin and albumin by human trophoblast. J Clin Endocrinol Metab 90, 6714-6720.

10. Dutriez-Casteloot I, Breton C, Coupé B, et al. (2008) Tissuespecific programming expression of glucocorticoid receptors and 11 beta-HSDs by maternal perinatal undernutrition in the HPA axis of adult male rats. Horm Metab Res 40, 257-261.

11. Kapoor A, Leen J \& Matthews SG (2008) Molecular regulation of the hypothalamic-pituitary-adrenal axis in adult male guinea pigs after prenatal stress at different stages of gestation. J Physiol 586, 4317-4326.

12. Arora S (2008) Leptin and its metabolic interactions: an update. Diabetes Obes Metab 10, 973-993. 
13. Adam CL, Findlay PA, Chanet A, et al. (2008) Expression of energy balance regulatory genes in the developing ovine fetal hypothalamus at midgestation and the influence of hyperglycemia. Am J Physiol Regul Integr Comp Physiol 294, 1895-1900.

14. Groothuis TG \& Schwabl H (2008) Hormone-mediated maternal effects in birds: mechanisms matter but what do we know of them? Philos Trans $R$ Soc Lond B Biol Sci 363, $1647-1661$

15. Groothuis TG, Muller W, von Engelhardt N, et al. (2005) Maternal hormones as a tool to adjust offspring phenotype in avian species. Neurosci Biobehav Rev 29, 329-352.

16. Hayward LS, Satterlee DG \& Wingfield JC (2005) Japanese quail selected for high plasma corticosterone response deposit high levels of corticosterone in their eggs. Physiol Biochem Zool 78, 1026-1031.

17. Wilson CM \& McNabb FM (1997) Maternal thyroid hormones in Japanese quail eggs and their influence on embryonic development. Gen Comp Endocrinol 107, 153-165.

18. Hu Y, Ni Y, Ren L, et al. (2008) Leptin is involved in the effects of cysteamine on egg laying of hens, characteristics of eggs, and posthatch growth of broiler offspring. Poult Sci 87, $1810-1817$.

19. Scanes CG \& Griminger P (1990) Endocrine-nutrition interactions in birds. J Exp Zool Suppl 4, 98-105.

20. De Pablo F, Roth J, Hernandez E, et al. (1982) Insulin is present in chicken eggs and early chick embryos. Endocrinology 111, 1909-1916.

21. Li Y, Yuan L, Yang X, et al. (2007) Effect of early feed restriction on myofibre types and expression of growth-related genes in the gastrocnemius muscle of crossbred broiler chickens Br J Nutr 98, 310-319.

22. Williams TD, Ames CE, Kiparissis Y, et al. (2005) Layingsequence-specific variation in yolk oestrogen levels, and relationship to plasma oestrogen in female zebra finches (Taeniopygia guttata). Proc Biol Sci 272, 173-177.

23. Livak KJ \& Schmittgen TD (2001) Analysis of relative gene expression data using real-time quantitative $\mathrm{PCR}$ and the 2(-Delta Delta $C(T)$ ) method. Methods 25, 402-408.

24. Lopez G \& Leeson S (1995) Response of broiler breeders to low-protein diets. 2. Offspring performance. Poult Sci 74, 696-701.

25. Bowmaker JE \& Gous RM (1991) The response of broiler breeder hens to dietary lysine and methionine. Br Poult Sci 32, 1069-1088.

26. Sechman A \& Bobek S (1988) Presence of iodothyronines in the yolk of the hen's egg. Gen Comp Endocrinol 69, 99-105.

27. Sharp PJ, Dunn IC, Waddington D, et al. (2008) Chicken leptin. Gen Comp Endocrinol 158, 2-4.

28. Dridi S, Williams J, Bruggeman V, et al. (2000) A chicken leptin-specific radioimmunoassay. Domest Anim Endocrinol 18, 325-335

29. Neglia S, Arcamone N, Gargiulo G, et al. (2008) Immunocytochemical detection of leptin-like immunoreactivity in the chicken gastroenteric tract. Gen Comp Endocrinol 155, 432-437.

30. Adachi H, Takemoto Y, Bungo T, et al. (2008) Chicken leptin receptor is functional in activating JAK-STAT pathway in vitro. $J$ Endocrinol 197, 335-342.

31. Dridi S, Taouis M, Gertler A, et al. (2007) The regulation of stearoyl-CoA desaturase gene expression is tissue specific in chickens. J Endocrinol 192, 229-236.

32. Figueiredo D, Gertler A, Cabello G, et al. (2007) Leptin downregulates heat shock protein-70 (HSP-70) gene expression in chicken liver and hypothalamus. Cell Tissue Res 329, 91-101.

33. Yang SJ \& Denbow DM (2007) Interaction of leptin and nitric oxide on food intake in broilers and leghorns. Physiol Behav 92, $651-657$.
34. Sirotkin AV \& Grossmann R (2007) Leptin directly controls proliferation, apoptosis and secretory activity of cultured chicken ovarian cells. Comp Biochem Physiol A Mol Integr Physiol 148, 422-429.

35. Fernandez-Twinn DS, Ozanne SE, Ekizoglou S, et al. (2003) The maternal endocrine environment in the low-protein model of intra-uterine growth restriction. Br J Nutr 90, 815-822.

36. de Beer M, McMurtry JP, Brocht DM, et al. (2008) An examination of the role of feeding regimens in regulating metabolism during the broiler breeder grower period. 2. Plasma hormones and metabolites. Poult Sci 87, 264-275.

37. Bautista CJ, Boeck L, Larrea F, et al. (2008) Effects of a maternal low protein isocaloric diet on milk leptin and progeny serum leptin concentration and appetitive behavior in the first 21 days of neonatal life in the rat. Pediatr Res 63, 358-363.

38. Zambrano E, Bautista CJ, Deás M, et al. (2006) A low maternal protein diet during pregnancy and lactation has sex- and window of exposure-specific effects on offspring growth and food intake, glucose metabolism and serum leptin in the rat. $J$ Physiol 571, 221-230.

39. McMillen IC, Edwards LJ, Duffield J, et al. (2006) Regulation of leptin synthesis and secretion before birth: implications for the early programming of adult obesity. Reproduction 131, 415-427.

40. Holdsworth CD \& Wilson TH (1967) Development of active sugar and amino acid transport in the yolk sac and intestine of the chicken. Am J Physiol 212, 233-240.

41. Powell KA, Deans EA \& Speake BK (2004) Fatty acid esterification in the yolk sac membrane of the avian embryo. J Comp Physiol B 174, 163-168.

42. Richards MP \& Poch SM (2003) Molecular cloning and expression of the turkey leptin receptor gene. Comp Biochem Physiol B Biochem Mol Biol 136, 833-847.

43. Lesage J, Sebaai N, Leonhardt M, et al. (2006) Perinatal maternal undernutrition programs the offspring hypothalamopituitary-adrenal (HPA) axis. Stress 9, 183-198.

44. Kucka M, Vagnerová K, Klusonová P, et al. (2006) Corticosterone metabolism in chicken tissues: evidence for tissue-specific distribution of steroid dehydrogenases. Gen Comp Endocrinol 147, 377-383

45. Gluckman PD, Lillycrop KA, Vickers MH, et al. (2007) Metabolic plasticity during mammalian development is directionally dependent on early nutritional status. Proc Natl Acad Sci U S A 104, 12796-12800.

46. Soprano DR, Soprano KJ \& Goodman DS (1986) Retinolbinding protein and transthyretin mRNA levels in visceral yolk sac and liver during fetal development in the rat. Proc Natl Acad Sci U S A 83, 7330-7334.

47. Southwell BR, Duan W, Tu GF, et al. (1991) Ontogenesis of transthyretin gene expression in chicken choroid plexus and liver. Comp Biochem Physiol B 100, 329-338.

48. Moran ET Jr (2007) Nutrition of the developing embryo and hatchling. Poult Sci 86, 1043-1049.

49. De Groef B, Grommen SV \& Darras VM (2008) The chicken embryo as a model for developmental endocrinology: development of the thyrotropic, corticotropic, and somatotropic axes. Mol Cell Endocrinol 293, 17-24.

50. Vieau D, Sebaai N, Leonhardt M, et al. (2007) HPA axis programming by maternal undernutrition in the male rat offspring. Psychoneuroendocrinology 32, Suppl. 1, S16-S20.

51. McMillen IC \& Robinson JS (2005) Developmental origins of the metabolic syndrome: prediction, plasticity, and programming. Physiol Rev 85, 571-633.

52. Go KS, Lingas R, Wheeler MB, et al. (2001) Decreased CRH mRNA expression in the fetal guinea pig hypothalamus following maternal nutrient restriction. Brain Res 896, 179-182. 
53. Vandenborne K, De Groef B, Geelissen SM, et al. (2005) Corticosterone-induced negative feedback mechanisms within the hypothalamo-pituitary-adrenal axis of the chicken. J Endocrinol 185, 383-391.

54. Nillni EA \& Sevarino KA (1999) The biology of pro-thyrotropinreleasing hormone-derived peptides. Endocr Rev 20, 599-648.

55. De Groef B, Vandenborne K, Van As P, et al. (2005) Hypothalamic control of the thyroidal axis in the chicken: over the boundaries of the classical hormonal axes. Domest Anim Endocrinol 29, 104-110.
56. Duclos MJ (2005) Insulin-like growth factor-I (IGF-1) mRNA levels and chicken muscle growth. $J$ Physiol Pharmacol 56, Suppl. 3, 25-35.

57. Lu JW, McMurtry JP \& Coon CN (2007) Developmental changes of plasma insulin, glucagon, insulin-like growth factors, thyroid hormones, and glucose concentrations in chick embryos and hatched chicks. Poult Sci 86, 673-683.

58. Duclos MJ (1998) Regulation of chicken muscle growth by insulin-like growth factors. Ann N Y Acad Sci 839, $166-171$ 